\title{
Synthesis and characterization of the first doubly-bridging pyridine-2-thionate (pys) molybdenum complex: crystal structure of $\left[\mathrm{Mo}\left(\eta^{3}-\mathrm{C}_{3} \mathrm{H}_{5}\right)(\mathrm{CO})_{2}\right]_{2}\left(\eta^{1}: \eta^{2}: \mu-\mathrm{pyS}\right)_{2}$
}

\author{
Kuang-Hway Yih ${ }^{\mathrm{a}, *}$, Gene-Hsiang Lee ${ }^{\mathrm{b}}$, Yu Wang ${ }^{\mathrm{c}}$ \\ ${ }^{a}$ Department of Applied Cosmetology, Hung Kuang Institute of Technology, 34 Chung Chi Road, Shalu, Taichung shien, Taiwan 433, ROC \\ ${ }^{\mathrm{b}}$ Instrumentation Center, College of Science, National Taiwan University, Taiwan 106, ROC \\ ${ }^{\mathrm{C}}$ Department of Chemistry, National Taiwan University, Taiwan 106, ROC
}

Received 23 July 2002; accepted 6 November 2002

\begin{abstract}
The doubly-bridging pyridine-2-thionate (pyS) molybdenum complexes $\left[\mathrm{Mo}\left(\eta^{3}-\mathrm{C}_{3} \mathrm{H}_{4} \mathrm{R}\right)(\mathrm{CO})_{2}\right]_{2}\left(\eta^{1}: \eta^{2}: \mu-p y S\right)_{2} \quad(\mathrm{R}=\mathrm{H}, \mathbf{1 a}$; $\left.\mathrm{CH}_{3}, \mathbf{1 b}\right)$ are accessible by the reaction of $\left[\mathrm{Mo}\left(\eta^{3}-\mathrm{C}_{3} \mathrm{H}_{4} \mathrm{R}\right)(\mathrm{CO})_{2}\left(\mathrm{CH}_{3} \mathrm{CN}\right)_{2} \mathrm{Br}\right]$ with pySK in $\mathrm{CH}_{2} \mathrm{Cl}_{2}$ at room temperature. Complexes 1a and $\mathbf{1 b}$ are dimers with each pyS unit chelating through sulfur and nitrogen to one metal center and bridging both metals through sulfur. Treatment of $\mathbf{1 a}$ with piperidine affords complex $\left[\mathrm{Mo}\left(\eta^{3}-\mathrm{C}_{3} \mathrm{H}_{5}\right)\left(\eta^{2}-\mathrm{pyS}\right)\left(\mathrm{C}_{5} \mathrm{H}_{10} \mathrm{NH}\right)(\mathrm{CO})_{2}\right](\mathbf{2})$. Complex 1a is characterized by X-ray diffraction analysis.
\end{abstract}

(C) 2002 Elsevier Science B.V. All rights reserved.

Keywords: Doubly-bridging; Pyridine-2-thionate; Molybdenum; X-ray diffraction

Molybdenum complexes containing Mo-S and Mo$\mathrm{N}$ bonds are of special interest because of their relevance to a variety of molybdenum-containing enzymes [1] and hydrodesulfurization catalysts [2]. To date, a variety of allyl complexes of molybdenum(II) containing bidentate anionic sulfur donor ligands such as dithiocarbamates have been described [3a]. Notably, the 16-electron allyl dithio complexes such as $\left[\mathrm{Mo}\left(\eta^{3}\right.\right.$-allyl $)\left(\eta^{2}-\mathrm{S}_{2} \mathrm{CNR}\right)$ $\left.(\mathrm{CO})_{2}\right]\left(\mathrm{R}=\mathrm{Et}, \mathrm{C}_{4} \mathrm{H}_{8}\right)[3 \mathrm{~b}]$ and $\left[\mathrm{Mo}\left(\eta^{3}\right.\right.$-allyl $)\left(\eta^{2}-\mathrm{Pz}_{2}^{*}\right.$ $\left.\mathrm{BR}_{2}\right)(\mathrm{CO})_{2}$ ] $(\mathrm{R}=\mathrm{H}, \mathrm{Et}, \mathrm{Ph})[4]$ and the 18-electron allyl dithio complexes $\left[\mathrm{Mo}\left(\eta^{3}\right.\right.$-allyl $)\left\{\eta^{3}-\mathrm{S}_{2} \mathrm{P}\left(\mathrm{OEt}_{2}\right)\right\}$ $\left.\left(\mathrm{CH}_{3} \mathrm{CN}\right)(\mathrm{CO})_{2}\right]$ [5] and $\left[\mathrm{Mo}\left(\eta^{3}\right.\right.$-allyl $)\left(\eta^{2}-\mathrm{S}_{2} \mathrm{COEt}\right)$ $\left(\mathrm{CH}_{3} \mathrm{CN}\right)(\mathrm{CO})_{2}$ ] [6] containing the sulfur or nitrogen bidentate ligands have been studied clearly. However, no detailed information has been presented on a mixed bidentate $(\mathrm{N}, \mathrm{S})$ ligand such as pySH. In this paper, we describe the preparation and characterization of the first doubly-bridging pyS allyl molybdenum(II) complex $\left[\mathrm{Mo}\left(\eta^{3}-\mathrm{C}_{3} \mathrm{H}_{4} \mathrm{R}\right)(\mathrm{CO})_{2}\right]_{2}\left(\eta^{1}: \eta^{2}: \mu-p y S\right)_{2}$.

\footnotetext{
${ }^{*}$ Corresponding author. Fax: +886-4-26321046.

E-mail address: khyih@sunrise.hkc.edu.tw (K.-H. Yih).
}

A number of 16 electron allyl complexes of the type $\left[\mathrm{Mo}\left(\eta^{3}-\mathrm{C}_{3} \mathrm{H}_{5}\right)\left(\eta^{2}-\mathrm{S}_{2} \mathrm{CNR}_{2}\right)(\mathrm{CO})_{2}\right]\left(\mathrm{R}_{2}=\mathrm{Me}, \mathrm{Et}\right.$, $\mathrm{C}_{4} \mathrm{H}_{8}, \mathrm{C}_{5} \mathrm{H}_{10}$ ) have been prepared from the reaction of $\left[\mathrm{Mo}\left(\eta^{3}-\mathrm{C}_{3} \mathrm{H}_{5}\right)(\mathrm{CO})_{2}(\mathrm{AN})_{2}(\mathrm{Br})\right]$ and $\mathrm{NaS}_{2} \mathrm{CNR}$ ligand [3b]. We expected the reaction of $\left[\mathrm{Mo}\left(\eta^{3}-\mathrm{C}_{3} \mathrm{H}_{5}\right)\right.$ $\left.(\mathrm{CO})_{2}(\mathrm{AN})_{2}(\mathrm{Br})\right]$ with pyridine-2-thionate would produce a 16 electron pyridine-2-thionate complex $\left[\mathrm{Mo}\left(\eta^{3}-\mathrm{C}_{3} \mathrm{H}_{5}\right)\left(\eta^{2}\right.\right.$-pyS $\left.)(\mathrm{CO})_{2}\right]$ or an 18 electron acetonitrile solvate complex $\left[\mathrm{Mo}\left(\eta^{3}-\mathrm{C}_{3} \mathrm{H}_{5}\right)\left(\eta^{2}-\right.\right.$ pyS $)$ $\left.\left(\mathrm{CH}_{3} \mathrm{CN}\right)(\mathrm{CO})_{2}\right]$. Instead, the product of this reaction was found to be a dimer, $\left[\mathrm{Mo}\left(\eta^{3}-\mathrm{C}_{3} \mathrm{H}_{5}\right)(\mathrm{CO})_{2}\right]_{2}$ $\left(\eta^{1}: \eta^{2}: \mu-p y S\right)_{2}$. Equimolar quantities of complex $\left[\mathrm{Mo}\left(\eta^{3}-\mathrm{C}_{3} \mathrm{H}_{4} \mathrm{R}\right)(\mathrm{AN})_{2}(\mathrm{CO})_{2} \mathrm{Br}\right]$ and pySK react in $\mathrm{CH}_{2} \mathrm{Cl}_{2}$ at room temperature to give the novel doublybridging pyS complexes $\left[\mathrm{Mo}\left(\eta^{3}-\mathrm{C}_{3} \mathrm{H}_{4} \mathrm{R}\right)(\mathrm{CO})_{2}\right]_{2}$ $\left(\eta^{1}: \eta^{2}: \mu-p y S\right)_{2}\left(\mathrm{R}=\mathrm{H}, \mathbf{1 a} ; \mathrm{CH}_{3}, \mathbf{1 b}\right)$ with a good yield (Scheme 2). The yellow complexes $\mathbf{1 a}$ and $\mathbf{1 b}$ are soluble in DMSO and slightly soluble in $\mathrm{CH}_{2} \mathrm{Cl}_{2}, \mathrm{CH}_{3} \mathrm{CN}$ and THF. The IR spectra of $\mathbf{1 a}$ and $\mathbf{1 b}$ [7] show four terminal carbonyl stretching bands and this phenomenon is similar to other 16-electron complexes $\left[\mathrm{Mo}\left(\eta^{3}\right.\right.$-allyl $)$ $\left.\left(\eta^{2}-\mathrm{L}\right)(\mathrm{CO})_{2}\right]\left(\mathrm{L}=\mathrm{Et}_{2} \mathrm{NCS}_{2}, \mathrm{C}_{4} \mathrm{H}_{8} \mathrm{NCS}_{2}, \mathrm{C}_{5} \mathrm{H}_{10} \mathrm{NCS}_{2}\right.$, $\left.\mathrm{Et}_{2} \mathrm{BPz}_{2}, \quad \mathrm{Ph}_{2} \mathrm{BPz}_{2}\right)$, which was crystallographically 


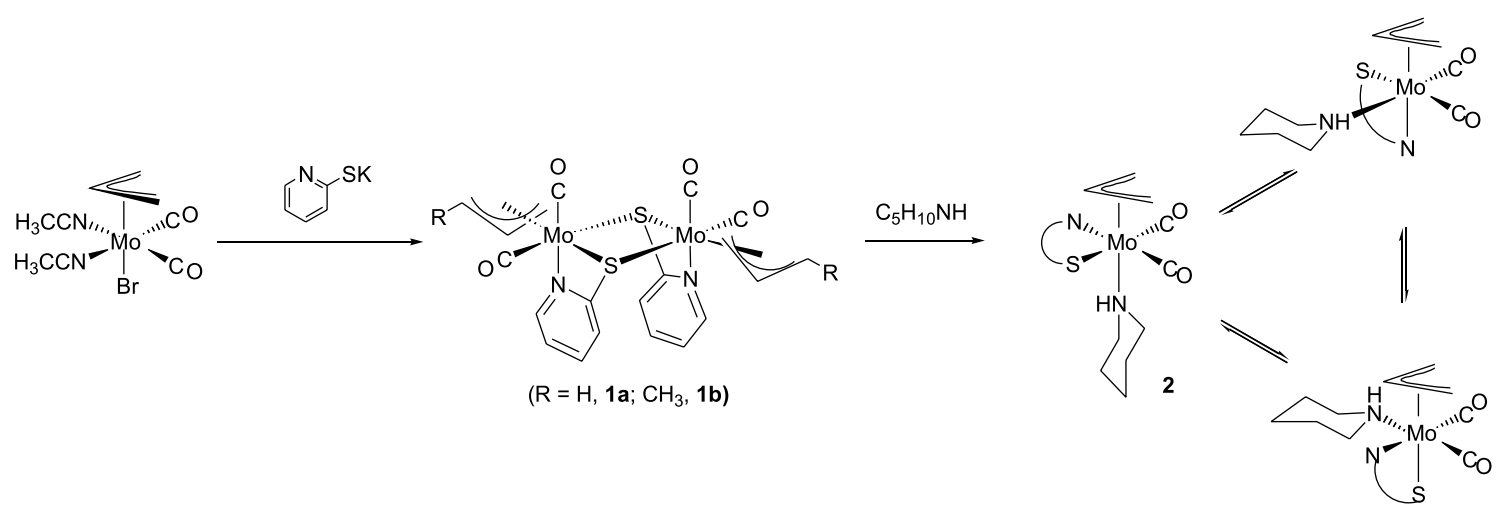

Scheme 1.

characterized in the case of $\mathrm{L}=\mathrm{Et}_{2} \mathrm{BPz}_{2}$ [4]. However, we cannot obtain the parent peak $\left[\mathrm{M}^{+}\right]$molecular mass with the typical Mo isotope distribution of 1a from the FAB mass spectrum. The room-temperature ${ }^{1} \mathrm{H}$ NMR spectrum shows five allyl proton resonances at $\delta 1.00$, 1.33, 3.06, 3.43 and 3.83, and the ${ }^{13} \mathrm{C}\left\{{ }^{1} \mathrm{H}\right\}$ NMR spectrum of 1a reveals two singlets at lowest field, which are assigned to the carbon atoms of the two terminal carbonyl groups. The ${ }^{1} \mathrm{H}$ and ${ }^{13} \mathrm{C}\left\{{ }^{1} \mathrm{H}\right\}$ NMR spectra assignment of $\mathbf{1 a}$ are determined by ${ }^{1} \mathrm{H}-{ }^{1} \mathrm{H}$ COSY and ${ }^{1} \mathrm{H}-{ }^{13} \mathrm{C}$ HMQC experiments. Thus it is clear that the allyl and the two carbonyl groups of 1a show a chemical nonequivalent environment. Because only one methyl and Hsyn resonance of $\mathbf{1 b}$ were detected in ${ }^{1} \mathrm{H}$ NMR spectrum, complex $\mathbf{1 b}$ is not a mixture of diastereomers and the two methyl groups are in the syn position respect to the Hcenter of the allyl ligand of $\mathbf{1 b}$.

To demonstrate the structure of the first allyl pyridine-2-thionate VIB group compound, complex 1a was confirmed by single-crystal X-ray diffraction study [8]. The ORTEP diagram with atom labels is shown in Fig. 1. Complex 1a is a dimer with each pyS unit chelating through sulfur and nitrogen to one metal center and bridging both metals through sulfur. The Mo-S distances are not equal and the $\mathrm{Mo}_{2} \mathrm{~S}_{2}$ ring is non-planar with a dihedral angle of $31.15(4)^{\circ}$ between the $\operatorname{Mo}(1) \mathrm{S}(1) \mathrm{Mo}(1 \mathrm{~A})$ and $\mathrm{Mo}(1) \mathrm{S}(1 \mathrm{~A}) \mathrm{Mo}(1 \mathrm{~A})$ planes. What distortions there are from octahedral geometry appear to be associated with the small interligand angle $64.43(12)^{\circ}$ (SMoN angles in chelate rings) and $95.70(5)^{\circ}$ (SMoS angles). The structure confirms unequivalent allyl groups. The sulfur atom of the pyS ligand is trans to the allyl: $\mathrm{S}(1)-\mathrm{Mo}(1)-\mathrm{C}(4), 152.60(18)^{\circ}$, whereas the nitrogen atom of pyS ligand is trans to one carbonyl: $\mathrm{N}(1)-\mathrm{Mo}(1)-\mathrm{C}(1), 166.5(2)^{\circ}$. The remaining carbonyl is trans to the sulfur atom of another pyS ligand: $\mathrm{S}(1 \mathrm{~A})-$ $\mathrm{Mo}(1)-\mathrm{C}(2), 159.95(18)^{\circ}$. The molybdenum-sulfur bond $2.5669(14) \AA$ (trans to allyl) is significantly shorter than the molybdenum-sulfur bond 2.6184(14) $\AA$ (trans to

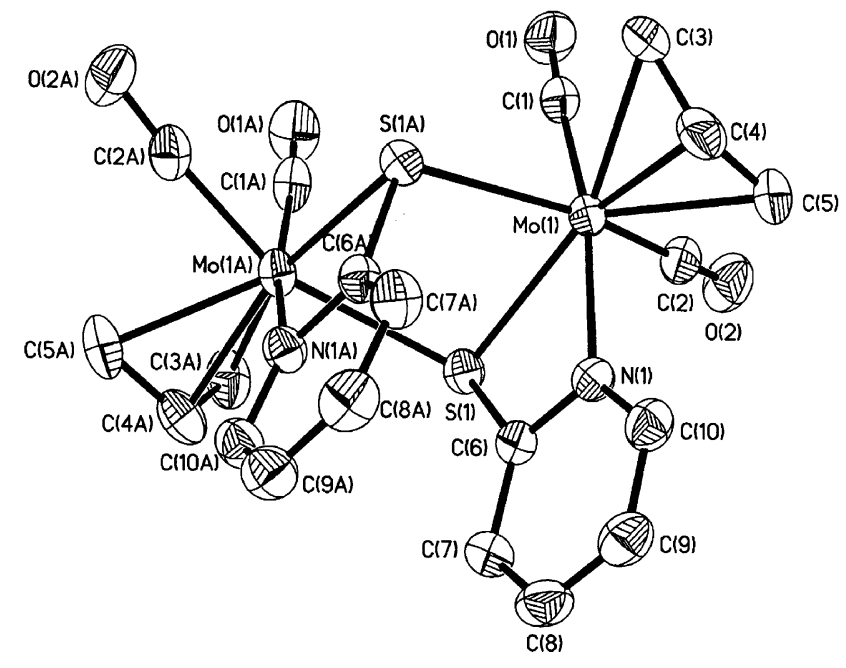

Fig. 1. ORTEP plot of the molecular structure with atom numbering scheme of complex $\left[\mathrm{Mo}\left(\eta^{3}-\mathrm{C}_{3} \mathrm{H}_{5}\right)(\mathrm{CO})_{2}\right]_{2}\left(\eta^{1}: \eta^{2}: \mu-p y S\right)_{2}$ (1a). Selected bond distances $(\AA)$ and angles $\left(^{\circ}\right)$ are as follows: $\operatorname{Mo}(1)-\mathrm{C}(1)$, 1.970(7); $\mathrm{Mo}(1)-\mathrm{C}(2), 1.948(7) ; \operatorname{Mo}(1)-\mathrm{C}(3), 2.349(6) ; \operatorname{Mo}(1)-\mathrm{C}(4)$, 2.209(6); $\mathrm{Mo}(1)-\mathrm{C}(5), 2.305(6) ; \operatorname{Mo}(1)-\mathrm{N}(1), 2.253(5) ; \operatorname{Mo}(1)-\mathrm{S}(1)$, 2.5669(14); $\mathrm{Mo}(1)-\mathrm{S}(1 \mathrm{~A}), \quad 2.6184(14) ; \mathrm{N}(1)-\mathrm{Mo}(1)-\mathrm{S}(1), \quad 64.43(12) ;$ $\mathrm{C}(4)-\mathrm{Mo}(1)-\mathrm{S}(1), \quad 152.60(18) ; \quad \mathrm{N}(1)-\mathrm{Mo}(1)-\mathrm{C}(1), \quad 166.5(2) ; \mathrm{S}(1 \mathrm{~A})-$ $\mathrm{Mo}(1)-\mathrm{C}(2), 159.95(18) ; \mathrm{S}(1 \mathrm{~A})-\mathrm{Mo}(1)-\mathrm{N}(1), 86.74(11) ; \mathrm{C}(1)-\mathrm{Mo}(1)-$ C(2), 77.9(2); C(1)-Mo(1)-S(1), 102.09(18); C(3)-C(4)-C(5), 116.1(7).

carbonyl) because of the greater trans effect induced by the CO group than the allyl group. The $\mathrm{S}(1)-\mathrm{Mo}(1)$ $\mathrm{N}(1)$ angle of $64.43(12)^{\circ}$ in 1a is similar to $63.6(1)^{\circ}$ in $\mathrm{Mo}_{2}(\mathrm{CO})_{9}\left(\mathrm{C}_{5} \mathrm{H}_{4} \mathrm{NS}\right)$ [9] within the range of experimental error. The Mo-C(3), C(4) and $\mathrm{C}(5)$ bond distances are 2.349(6), 2.209(17) and 2.253(5) ^, respectively. The bond distances and intercarbon angle of allyl group in 1a (1.393(8), 1.394(7) $\AA$ and 116.1(7) $\AA$ ) is insignificantly different and in the region of related $\mathrm{Mo}^{\mathrm{II}}$-allylic compounds $\left(1.31-1.42 \AA, 115-125^{\circ}\right)$ [10]. The Mo-Mo distance is $3.8446(9) \AA$, indicating no significant metal-metal interaction. To our knowledge, a Group VIB complex containing $\mathrm{M}-\mathrm{S}$ and $\mathrm{M}-\mathrm{N}$ bonds involving a pyridine-2-thionate (pyS) moiety as 


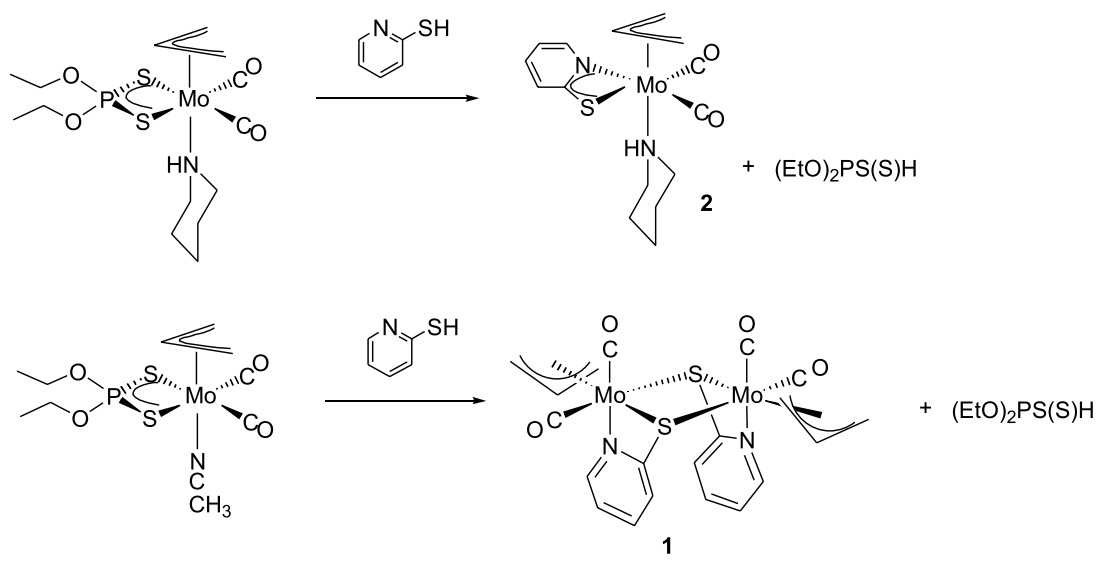

Scheme 2 .

a doubly-bridging bidentate ligand has not been reported in the literature, although Group VB [11], Group VIIB [12] and Group VIIIB [13] metal complexes with pyS ligands are known.

Although the dinuclear compound 1a is apparently strongly held by sulfur bridges and is thermally stable, these bridges are easily cleaved by addition of $\sigma$ donor ligands. Thus treatment of $\mathbf{1 a}$ with $\mathrm{C}_{5} \mathrm{H}_{10} \mathrm{NH}$ at ambient temperature yields a mononuclear complex [Mo $\left(\eta^{3}-\mathrm{C}_{3} \mathrm{H}_{5}\right)\left(\eta^{2}-\right.$ pyS $\left.)\left(\mathrm{C}_{5} \mathrm{H}_{10} \mathrm{NH}\right)(\mathrm{CO})_{2}\right]$ (2) in good yield (Scheme 1) in which the pyS ligand acts as a chelating three-electron (counted as a radical) ligand. The yellow compound $\mathbf{2}$ is slightly air-sensitive, soluble in polar solvent, and slightly soluble in $n$-hexane. The FAB mass spectrum of $\mathbf{2}$ shows a parent peak corresponding to the $\left[\mathrm{M}^{+}\right]$molecular mass. Similar spectroscopic phenomena of the carbonyl group and allyl moiety in IR, ${ }^{1} \mathrm{H}$, and ${ }^{13} \mathrm{C}\left\{{ }^{1} \mathrm{H}\right\}$ NMR spectra [7] lead us to believe that complex 2 contains the similar intramolecular trigonal twist rotational behavior as those of the 18 electron dithiophosphate complexes $\left[\mathrm{Mo}\left(\eta^{3}-\mathrm{C}_{3} \mathrm{H}_{5}\right)\left\{\eta^{3}-\mathrm{S}_{2} \mathrm{P}\left(\mathrm{OEt}_{2}\right)\right\}\right.$ $\left.\left(\mathrm{CH}_{3} \mathrm{CN}\right)(\mathrm{CO})_{2}\right]$ [5], [ $\mathrm{Mo}\left(\eta^{3}-\mathrm{C}_{3} \mathrm{H}_{5}\right)\left\{\eta^{3}-\mathrm{S}_{2} \mathrm{P}\left(\mathrm{OEt}_{2}\right)\right\}\left(\mathrm{C}_{5}\right.$ $\left.\left.\mathrm{H}_{10} \mathrm{NH}\right)(\mathrm{CO})_{2}\right]$ [5] and the dithiocarbonate complex $\left[\mathrm{Mo}\left(\eta^{3}-\mathrm{C}_{3} \mathrm{H}_{5}\right)\left(\eta^{2}-\mathrm{S}_{2} \mathrm{COEt}_{2}\right)\left(\mathrm{CH}_{3} \mathrm{CN}\right)(\mathrm{CO})_{2}\right]$ [6]. Treatment of 2 with $\mathrm{CS}_{2}$ no 16 electron dithiocarbamate complex $\left[\mathrm{Mo}\left(\eta^{3}-\mathrm{C}_{3} \mathrm{H}_{5}\right)\left(\eta^{2}-\mathrm{S}_{2} \mathrm{CNC}_{5} \mathrm{H}_{10}\right)(\mathrm{CO})_{2}\right]$ can be obtained. Complexes $\mathbf{1}$ and $\mathbf{2}$ can be prepared by the reactions of $\left[\mathrm{Mo}\left(\eta^{3}-\mathrm{C}_{3} \mathrm{H}_{5}\right)\left\{\eta^{3}-\mathrm{S}_{2} \mathrm{P}\left(\mathrm{OEt}_{2}\right)\right\}\left(\mathrm{CH}_{3}\right.\right.$ $\left.\mathrm{CN})(\mathrm{CO})_{2}\right],\left[\mathrm{Mo}\left(\eta^{3}-\mathrm{C}_{3} \mathrm{H}_{5}\right)\left\{\eta^{3}-\mathrm{S}_{2} \mathrm{P}\left(\mathrm{OEt}_{2}\right)\right\}\left(\mathrm{C}_{5} \mathrm{H}_{10} \mathrm{NH}\right)\right.$ $(\mathrm{CO})_{2}$ ] and pySH with releasing of the $(\mathrm{EtO})_{2} \mathrm{P}(\mathrm{S}) \mathrm{SH}$ ligand, respectively (Scheme 2). Attempt to synthesis a bisalkyne product as that of complex $\left[\mathrm{Mo}(\mathrm{PhC} \equiv \mathrm{CPh})_{2}\right.$ $\left.\left\{\eta^{2}-\mathrm{S}_{2} \mathrm{P}\left(\mathrm{OEt}_{2}\right)\right\}_{2}\right]$ [14] from the reaction of $\mathbf{1 a}$ with diphenylacetylene, no reaction occurred even in refluxing acetonitrile for $1 \mathrm{~h}$. From the mention of above, one can conclude that the pySH ligand is a stronger $\pi$-accepter ligand than the $(\mathrm{EtO})_{2} \mathrm{P}(\mathrm{S}) \mathrm{SH}$ ligand. Currently, the reactions of $1 \mathrm{a}$ with nitrogen, sulfur and phosphorus ligands are under investigation.

\section{Acknowledgements}

We thank the National Science Council of Taiwan, the Republic of China for support.

\section{References}

[1] S.P. Cramer, K.O. Hodgson, W.O. Gillum, L.E. Mortenson, J. Am. Chem. Soc. 100 (1978) 3398.

[2] K. Anzenhofer, J.J. de Boer, Acta Cryst. B 25 (1969) 1419.

[3] (a) M.R. Houchin, K. Mitsios, Inorg. Chim. Acta 65 (1982) L147; (b) K.B. Shiu, K.H. Yih, S.L. Wang, F.L. Liao, J. Organomet. Chem. 420 (1991) 359.

[4] (a) F.A. Cotton, A.G. Stanislowski, J. Am. Chem. Soc. 96 (1974) 5074

(b) S.F. Lush, S.H. Wang, G.H. Lee, S.M. Peng, S.L. Wang, R.S. Liu, Organometallics 9 (1990) 1862.

[5] K.H. Yih, G.H. Lee, Y. Wang, J. Organomet. Chem. 588 (1999) 125.

[6] K.H. Yih, G.H. Lee, Y. Wang, Hungkuang Journal 40 (2002) 1.

[7] Spectroscopy for 1a: IR (KBr, cm $\left.{ }^{-1}\right)$ v(CO) 1937(vs), 1922(vs), 1875(vs), 1858(vs). ${ }^{1} \mathrm{H}$ NMR (500 MHz, DMSO- $\left.d_{6}, 298 \mathrm{~K}\right): \delta$ $1.00,1.33\left(\mathrm{~d}, J_{\mathrm{H}-\mathrm{H}}=9.6 \mathrm{~Hz}, 2 \mathrm{H}\right.$, Hanti of allyl), 3.06, $3.43(\mathrm{br}, 2 \mathrm{H}$, Hsyn of allyl), $3.83\left(\mathrm{~m}, 1 \mathrm{H}, \mathrm{CH}\right.$ of allyl), $6.77\left(\mathrm{~d}, J_{\mathrm{H}-\mathrm{H}}=8.1 \mathrm{~Hz}\right.$, $1 \mathrm{H}, \mathrm{SCC} H), 6.83\left(\mathrm{t}, J_{\mathrm{H}-\mathrm{H}}=6.3 \mathrm{~Hz}, 1 \mathrm{H}, \mathrm{NCHCH}\right), 7.39(\mathrm{t}$, $\left.J_{\mathrm{H}-\mathrm{H}}=7.7 \mathrm{~Hz}, 1 \mathrm{H}, \mathrm{SCCHCH}\right), 7.88\left(\mathrm{~d}, J_{\mathrm{H}-\mathrm{H}}=4.6 \mathrm{~Hz}, 1 \mathrm{H}\right.$, $\mathrm{NC} H$ ). ${ }^{13} C\left\{{ }^{1} \mathrm{H}\right\}$ NMR (75 MHz, DMSO- $\left.d_{6}, 298 \mathrm{~K}\right): \delta 51.9,62.9$ (s, $\mathrm{C}=\mathrm{CH}_{2}$ ), 74.6 (s, $C=\mathrm{CH}_{2}$ ), 117.3 (s, 5-C of pyS), 126.2 (s, 3-C of pyS), 136.9 (s, 4-C of pyS), 146.2 (s, 6-C of pyS), 176.7 (s, 2-C of pyS), 228.9, 231.2 (s, CO). mp $195{ }^{\circ} \mathrm{C}$ dec. Anal. Calcd. for $\mathrm{C}_{20} \mathrm{H}_{18} \mathrm{~N}_{2} \mathrm{O}_{4} \mathrm{~S}_{2} \mathrm{Mo}_{2}$ : C, 39.61; H, 2.99; N, 4.62\%. Found: C, 39.80; $\mathrm{H}, 2.60$; N, 4.50. Spectroscopy for $\mathbf{1 b}$ : IR $\left(\mathrm{KBr}, \mathrm{cm}^{-1}\right) \mathrm{v}(\mathrm{CO})$ 1933(vs), 1915(vs), 1870(vs), 1849(vs). ${ }^{1} \mathrm{H}$ NMR (500 MHz, DMSO- $\left.d_{6}, 298 \mathrm{~K}\right): \delta 1.53\left(\mathrm{~d}, J_{\mathrm{H}-\mathrm{H}}=6.4 \mathrm{~Hz}, 2 \mathrm{H}\right.$, Hanti of allyl), 2.49 (br, 2H, Hanti of allyl), 3.45 (br, 2H, Hsyn of allyl), 3.92 (s, $6 \mathrm{H}, \mathrm{CH}_{3}$ syn of allyl), 4.34 (s, $2 \mathrm{H}, \mathrm{Hc}$ of allyl), $7.40\left(\mathrm{~d}, J_{\mathrm{H}-\mathrm{H}}=8.0\right.$ $\mathrm{Hz}, 2 \mathrm{H}, \mathrm{SCC} H), 7.46\left(\mathrm{t}, J_{\mathrm{H}-\mathrm{H}}=6.2 \mathrm{~Hz}, 2 \mathrm{H}, \mathrm{NCHCH}\right), 8.00(\mathrm{br}$, $2 \mathrm{H}, \mathrm{SCCHCH}), 8.56(\mathrm{br}, 2 \mathrm{H}, \mathrm{NCH}) .{ }^{13} \mathrm{C}\left\{{ }^{1} \mathrm{H}\right\}$ NMR $(125 \mathrm{MHz}$, $\left.\mathrm{CDCl}_{3}, 298 \mathrm{~K}\right): \delta 18.2\left(\mathrm{~s}, \mathrm{CH}_{3}\right), 45.8,62.9\left(\mathrm{~s}, C=\mathrm{CH}_{2}\right), 78.5(\mathrm{~s}$, $C=\mathrm{CH}_{2}$ ), 120.7 (s, 5-C of pyS), 129.1 (s, 3-C of pyS), 134.8 (s, 4-C of pyS), 148.3 (s, 6-C of pyS), 178.7 (s, 2-C of pyS), 225.9, 230.2 (s, CO). mp $205{ }^{\circ} \mathrm{C}$ dec. Anal. Calcd. for $\mathrm{C}_{22} \mathrm{H}_{22} \mathrm{~N}_{2} \mathrm{O}_{4} \mathrm{~S}_{2} \mathrm{Mo}_{2}: \mathrm{C}$, 41.65; H, 3.50; N, 4.42\%. Found: C, 41.82; H, 3.46; N, 4.31 . Spectroscopy for 2: IR (KBr, cm ${ }^{-1}$ ) v(CO) 1924(vs), 1838(vs). ${ }^{1} \mathrm{H}$ 
NMR (500 MHz, DMSO- $\left.d_{6}, 298 \mathrm{~K}\right): \delta 1.16,1.26\left(\mathrm{~d}, J_{\mathrm{H}-\mathrm{H}}=8.9\right.$ $\mathrm{Hz}, 2 \mathrm{H}$, Hanti of allyl), $1.64\left(\mathrm{~m}, 6 \mathrm{H}, \mathrm{NCH}_{2} \mathrm{CH}_{2} \mathrm{CH}_{2}\right), 2.88(\mathrm{~m}$, $\left.4 \mathrm{H}, \mathrm{NCH}_{2}\right), 3.20,3.51$ (br, $2 \mathrm{H}$, Hsyn of allyl), $3.60(\mathrm{~m}, 1 \mathrm{H}, \mathrm{CH}$ of allyl), 3.89 (br, 1H, NH), $6.71\left(\mathrm{t}, \mathrm{J}_{\mathrm{H}-\mathrm{H}}=6.1 \mathrm{~Hz}, 1 \mathrm{H}, \mathrm{NCHCH}\right)$, $6.87\left(\mathrm{~d}, \mathrm{~J}_{\mathrm{H}-\mathrm{H}}=8.2 \mathrm{~Hz}, 1 \mathrm{H}, \mathrm{SCC} H\right), 7.25\left(\mathrm{t}, J_{\mathrm{H}-\mathrm{H}}=7.1 \mathrm{~Hz}, 1 \mathrm{H}\right.$, SCCHCH), $7.67(\mathrm{br}, 1 \mathrm{H}, \mathrm{NCH}) .{ }^{13} \mathrm{C}\left\{{ }^{1} \mathrm{H}\right\} \mathrm{NMR}(125 \mathrm{MHz}$, DMSO- $\left.d_{6}, \quad 298 \mathrm{~K}\right): \quad \delta \quad 23.8 \quad\left(\mathrm{~s}, \quad \mathrm{NCH}_{2} \mathrm{CH}_{2} \mathrm{CH}_{2}\right), 25.1 \quad(\mathrm{~s}$, $\left.\mathrm{NCH}_{2} \mathrm{CH}_{2}\right), 46.1\left(\mathrm{~s}, \mathrm{NCH}_{2}\right), 54.2,62.6\left(\mathrm{~s}, \mathrm{C}=\mathrm{CH}_{2}\right), 70.7$ (s, $\left.C=\mathrm{CH}_{2}\right), 117.3$ (s, 5-C of pyS), 125.0 (s, 3-C of pyS), 136.0 (s, 4-C of pyS), 147.0 (s, 6-C of pyS), 170.3 (s, 2-C of pyS), 226.6 (s, CO). MS (FAB, NBA, m/z): $389\left[\mathrm{M}^{+}\right], 321\left[\mathrm{M}^{+}-\mathrm{CO}\right], 293$ [M+-2CO]. mp $187^{\circ} \mathrm{C}$ dec. Anal. Calcd for $\mathrm{C}_{15} \mathrm{H}_{19} \mathrm{~N}_{2} \mathrm{O}_{2} \mathrm{SMo}$ : C, 46.51; $\mathrm{H}$, $4.95 ; \mathrm{N}, 7.23 \%$. Found: C, 46.85; H, 5.01; N, 7.12.

[8] Crystal data for 1a: $\mathrm{C}_{20} \mathrm{H}_{18} \mathrm{~N}_{2} \mathrm{O}_{4} \mathrm{~S}_{2} \mathrm{Mo}_{2}\left(M_{r}=606.36\right)$; triclinic; space group $\mathrm{Pbcn}, \quad a=8.3128(1) \AA, \quad b=16.1704(2) \AA$, $c=16.6140(2) \quad \AA \quad V=2233.28(5) \AA^{3}, \quad Z=4, \quad \rho_{\text {calcd }}=1.803$ $\mathrm{gcm}^{-3}, \quad \mu=1.339 \mathrm{~mm}^{-1}$, observed reflections 14552, $\theta_{\text {range }}=$ 2.45-27.50 . Data were collected with $\mathrm{MoK} \alpha$ radiation $(\lambda=$ $0.71073 \AA$ ) on an Enraf-Nonius CAD4 diffractometer at 295(2) K. Total number of parameters: $137 . R_{1}=0.0510, w R_{2}=0.1063$; $G O F=1.159 ; \Delta F=1.670,-1.980 e \AA^{3}$.
[9] P. Yu, L. Huang, B. Zhuang, Acta Cryst. C 50 (1994) 1191.

[10] (a) A.J. Graham, R.H. Fenn, J. Organomet. Chem. 17 (1969) 405; (b) R.H. Fenn, A.J. Graham, J. Organomet. Chem. 37 (1972) 137; (c) J.W. Faller, D.F. Chodosh, D. Katahira, J. Organomet. Chem. 187 (1980) 227;

(d) A.J. Graham, D. Akrigg, B. Sheldrick, Cryst. Struct. Commun. 24 (1976) 173;

(e) B.J. Brisdon, D.A. Ewards, K.E. Paddick, M.G.B. Drew, J. Chem. Soc., Dalton Trans. (1980) 1317;

(f) C.A. Cosky, P. Ganis, G. Avatabile, Acta Crystallogr., Sect. B B 27 (1971) 1859.

[11] J.G. Reynolds, S.C. Sendlinger, A.M. Murray, J.C. Huffman, G. Christou, Inorg. Chem. 34 (1995) 5745.

[12] A.J. Ceeming, M. Karim, P.A. Bates, M.B. Hursthouse, Polyhedron 7 (1988) 1401.

[13] (a) N. Zhang, S.R. Wilson, P.A. Shapley, Organometallics 7 (1988) 1126;

(b) A.J. Ceeming, M. Karim, N.I. Powell, K.I. Hardcastle, Polyhedron 9 (1990) 623.

[14] K.H. Yih, G.H. Lee, S.L. Huang, Y. Wang, J. Organomet. Chem. 658 (2002) 191. 